\title{
Infrastructure procurement capacity gaps in Nigeria public sector institutions
}

DOI:

10.1108/ECAM-11-2017-0240

\section{Document Version}

Accepted author manuscript

Link to publication record in Manchester Research Explorer

\section{Citation for published version (APA):}

Manu, P., Mahamadu, A-M., Booth, C., Olomolaiye, P., Coker, A., Ibrahim, A. D., \& Lamond, J. (2019).

Infrastructure procurement capacity gaps in Nigeria public sector institutions. Engineering, Construction and Architectural Management. https://doi.org/10.1108/ECAM-11-2017-0240

\section{Published in:}

Engineering, Construction and Architectural Management

\section{Citing this paper}

Please note that where the full-text provided on Manchester Research Explorer is the Author Accepted Manuscript or Proof version this may differ from the final Published version. If citing, it is advised that you check and use the publisher's definitive version.

\section{General rights}

Copyright and moral rights for the publications made accessible in the Research Explorer are retained by the authors and/or other copyright owners and it is a condition of accessing publications that users recognise and abide by the legal requirements associated with these rights.

\section{Takedown policy}

If you believe that this document breaches copyright please refer to the University of Manchester's Takedown Procedures [http://man.ac.uk/04Y6Bo] or contact uml.scholarlycommunications@manchester.ac.uk providing relevant details, so we can investigate your claim.

\section{OPEN ACCESS}




\title{
Engineering Construction and Architectural Management
}

\author{
DOI: 10.1108/ECAM-11-2017-0240 \\ Accepted: 26 February 2019

\section{INFRASTRUCTURE PROCUREMENT CAPACITY GAPS IN NIGERIA PUBLIC SECTOR INSTITUTIONS}

${ }^{1}$ Patrick Manu*, ${ }^{1}$ Abdul-Majeed Mahamadu, ${ }^{1}$ Colin Booth, ${ }^{1}$ Paul Olomolaiye, ${ }^{2}$ Akinwale Coker, ${ }^{3}$ Ahmed Ibrahim and ${ }^{1}$ Jessica Lamond.

${ }^{1}$ Faculty of Environment and Technology, University of the West of England, Bristol, BS16 1QY, United Kingdom.

${ }^{2}$ Department of Civil Engineering, University of Ibadan, Ibadan, Nigeria.

${ }^{3}$ Department of Quantity Surveying, Ahmadu Bello University, Zaria, Nigeria.

${ }^{*}$ Corresponding author:

Dr Patrick Manu, Visiting Fellow.

Email: Patrick.Manu@uwe.ac.uk

\section{Acknowledgement}

Appreciation is extended to the United Kingdom Department for International Development (DfID) for funding this research as part of the Urbanisation Research Nigeria Programme. 


\section{ABSTRACT}

Purpose: The achievement of sustainable development goals is linked to the procurement of public infrastructure in a manner that meets key procurement objectives, such as sustainability, value-for-money, transparency and accountability. At the heart of achieving these procurement objectives and others is the capacity of public procurement institutions. Whereas previous reports have hinted that there are deficiencies in procurement capacity in Nigeria, insights regarding critical aspects of organisational capacity deficiencies among different tiers of government agencies is limited. This study investigates the critical gaps in the procurement capacity of state and local government agencies involved in the procurement of public infrastructure in Nigeria.

Design/methodology/approach: The study employed a survey of public infrastructure procurement personnel which yielded 288 responses.

Findings: Among 23 operationalised items that are related to organisational procurement capacity, none is perceived to be adequate by the procurement personnel. Additionally, among 14 procurement objectives only one is perceived as being attained to at least a high extent.

Originality/value: The findings underscore the acuteness of organisational procurement capacity weaknesses among public procurement institutions within Nigeria's governance structure. It is, thus, imperative for policy makers within state and local government to formulate, resource and implement procurement capacity building initiatives/programmes to address these deficiencies. Additionally, the organisational procurement capacity items operationalised in this study could serve as a useful blueprint for studying capacity deficiencies among public infrastructure procurement agencies in other developing countries, especially within sub-Saharan Africa where several countries have been implementing public procurement reforms.

Keywords: construction, engineering, questionnaire survey.

\section{Introduction}

Among the United Nation's Sustainable Development Goals (UN SDGs) are the provision of good health and well-being, clean water and sanitation, quality education, sustainable cities and communities, and affordable and clean energy (United Nations Economic and Social Council, 2016). Achievement of these goals is inextricably linked with the procurement of critical infrastructure such as water and waste treatment, power generation, transport, health, and educational infrastructures. In developing regions, especially in sub-Saharan Africa, there is an acute need of these infrastructures (United Nations Economic and Social Council, 2016). For instance, it is estimated that in 2014 , while $30 \%$ of the world's urban populace lived in slum-like condition, in sub-Saharan Africa alone, the proportion stood at 55\%, which is the highest of any region (United Nations Economic and Social Council, 2016). The poor state of infrastructure in this region is reflected by the situation in Nigeria where there is a deficit in the quantity and quality of infrastructure (African Development Bank (AfDB), 2013).

Besides the infrastructure deficits in Nigeria, their procurement is also fraught with challenges including deficiencies in the procurement capacity of public entities (World Bank, 2013). Given that government organisations (at various levels of governance) constitute a major procurer of goods, works and services (including infrastructure 
assets) the world over, including in Nigeria (Organisation for Economic Co-operation and Development (OECD) and World Bank, 2004; United Nations Development Programme (UNDP), 2010; AfDB, 2013), it is imperative that these organisations have adequate capacity in respect of procurement in order to achieve modern procurement objectives which include sustainability, value-for-money, transparency, and many others. This study sought to establish the critical gaps in the capacity of state and local government agencies involved in the procurement of public infrastructure in Nigeria. In the following sections, an overview of the status of infrastructure and public procurement in Nigeria is presented. This is extended to cover a review of procurement capacity literature with the view to identifying elements/areas of organisational procurement capacity. Subsequent to this, the research strategy applied in this study, the ensuing findings, discussion, implications and concluding remarks are given.

\section{Overview of the Status of Infrastructure \& Public Procurement in Nigeria}

Infrastructure is estimated to make a net contribution of around one percentage point to Nigeria's per capita growth with improvements in infrastructure expected to boost annual growth by around four percentage points (Foster and Pushak, 2011). Nigeria's infrastructure, however, remains inadequate in terms of its quantity and quality (Agu and Onodugo, 2009; Foster and Pushak, 2011; AfDB, 2013). This covers various types of infrastructure, such as power generation infrastructure, transport, housing, water and sanitation, and health (Foster and Pushak, 2011; AfDB, 2013; Veitch, 2014). For example, due to the poor state of energy infrastructure, it is estimated that the average per capita consumption of electricity is only about $150 \mathrm{kWh}$ per annum as compared to the UK average of 5,500kWh (Veitch, 2014). Additionally, housing deficit in Nigeria is estimated to be at about 17 million units (Veitch, 2014).

Recognition of the importance of infrastructure to socio-economic development has over the years triggered various initiatives that have been implemented to facilitate infrastructure provision. These include Nigeria's governmental programmes e.g. National Integrated Infrastructure Master Plan (NIIMP), which is estimated to cost US\$2.9 trillion over 30 years (Veitch, 2014), as well as donor agency supported programmes to improve delivery of municipal services through infrastructure procurement e.g. the Nigerian Infrastructure Advisory Facility (NIAF) (Foster and Pushak, 2011; AfDB, 2013; NIAF, 2016). In spite of these investments/initiatives, Nigeria's infrastructure deficit has loomed due to a myriad of public procurement challenges including financing, ineffectiveness of tender boards, lack of professionalism, lack of competition and transparency, and deficiency in procurement capacity (World Bank, 1995, 2000; The Budget Monitoring and Price Intelligence Unit (BMPIU), 2005; Agu and Onodugo, 2009; World Bank, 2013). On the back of the public procurement challenges, there have been procurement reforms that have in the main focussed on regulatory frameworks aimed at achieving procurement objectives including transparency, competition, value-for-money, cost effectiveness, and accountability (Ocheni and Nwankwo, 2012). Prominent among the procurement reforms is the Public Procurement Act 2007 (PPA 2007) which harmonises government practices and policies for public procurement.

The PPA comprises 13 parts and 61 sections. The Act stipulates the need for the establishment of procurement units in each governmental Ministry, Department and Agency (MDA) to oversee the compliance and adherence to the Act in the 
procurement of works, goods and services. MDAs work across Nigeria's governance structure including Federal (national), State and Local Government tiers. These MDAs are responsible for the procurement of infrastructure in general. The Act further stipulates the composition of procurement units and boards to include civil society, in order to ensure transparency, accountability and participation (World Bank, 2013).

At the spate of Nigeria's urban population growth, state and local government agencies (SLGAs) are increasingly being relied on for acceleration of economic development in their municipalities (Ekumankama et al., 2012). This primarily requires capital expenditure on infrastructure projects that are key to the delivery of municipal services (Agu and Onodugo, 2009). Since reforms in the 1970's, the SLGAs have been viewed as the second and third tier of government respectively operating within institutional frameworks with defined functions and responsibilities. State Governments generate their own income and also rely on statutory allocations from Federal Government. As the third tier of government, the Local Government Agencies (LGAs) get statutory grants from the State Governments. Generally, SLGAs are expected to serve as agents of development in their local jurisdiction based on funds generated or available to them. SLGAs are therefore required to establish procurement units with requisite staff to manage the implementation of the PPA 2007 in the procurement of works, goods and services. Despite the key role of SLGAs in infrastructure provision, their role has been adversely impacted by capacity constraints (Agu and Onodugo, 2009). More recently, the inadequate capacity by procurement entities to effectively manage procurement process has again been reported as one of the challenges to the attainment of procurement objectives (World Bank, 2013). The following section examines procurement capacity.

\section{Procurement Capacity}

Capacity is the "ability of people, organisations/institutions and society as a whole to successfully manage their affairs" (OECD, 2006, p. 12). It is often used in relation to procurement capacity development, which is described by the United Nations (UN) as the process through which individuals, organisations and societies obtain, strengthen, and maintain the capabilities to set and achieve their own development objectives over time (UNDP, 2010). Procurement capacity can be conceived as being three-pronged: individual; organisational; and environmental/national (OECD and World Bank 2004; UNDP, 2010). While the individual facet looks at the skills, knowledge and experience of procurement staff/personnel, the organisational facet looks at procurement policies, procedures and frameworks within procurement organisations, and the environmental facet looks at national policies, legislation, frameworks and guidance that govern procurement (OECD and World Bank 2004; UNDP, 2010). Given the focus of this study on organisational capacity, this aspect is considered further below.

Regarding the organisational facet of procurement capacity, frameworks have highlighted key areas/elements of procurement capacity which are around material resources, human resources and organisation processes/procedures that create of an enabling organisational environment, as well as intensification of managerial systems (Jensen, 2009; UNDP, 2010). For example, the following areas of organisational capacity are considered as part of the Millennium Challenge Corporation's (MCC) procurement maturity model: staffing (recruiting); human resources competencies 
development (e.g. training and mentoring); career path development (e.g. retaining and promotion); procurement management; procurement organisation; performance management; information systems management; risk management; leadership and organisational culture (Meyer, 2014).

The OECD and World Bank (2004) similarly highlight the following as key organisational procurement capacity areas: organisational structure; staffing profile; budgeting and planning process; information technology infrastructure and skills; and human resources function. The UNDP (2006) summarises organisational procurement capacity as comprising eight core areas: leadership; policy and legal framework; mutual accountability mechanisms; public engagement; human resources; financial resources; and environmental resources. Table 1 provides a summary of organisational capacity areas/elements drawn from various literature sources.

Studies in several domains (e.g. Smits et al., 2016; Devece et al., 2017; Mahamadu et al., 2018) have shown that organisational capacity or capability has an effect on performance. For example, Devece et al. (2017) in their study of the effect of information management capability on organisational performance, found a causal link between information management capability and three measures of organisational performance (i.e. competitive position, productivity, and customer satisfaction). Smits et al. (2016) also found a relationship between building information modelling (BIM) implementation strategy, an aspect of BIM capability, and construction project performance (i.e. time, cost and quality performance). Furthermore, recent work by Mahamadu et al. (2018) has reported causal relationships between BIM capability and BIM delivery success. In view of the foregoing discussion, regarding infrastructure procurement capacity at the organisational level, which can be viewed as the ability of an organisation to successfully achieve procurement objectives regarding infrastructure provision (UNDP, 2010), public infrastructure procurement entities would need to have adequate capacity in order to effectively attain infrastructure procurement objectives. Despite the reported procurement capacity constraints in Nigeria (Agu and Onodugo, 2009; Fayomi, 2013), there is a lack of a detailed analysis of the procurement capacity areas of SLGAs to identify the critical aspects of deficiency, as well as the extent of attainment of procurement objectives in the procurement of infrastructure.

[Insert Table 1]

\section{Research Methodology}

A quantitative approach, in particular a structured questionnaire survey, was adopted in order to obtain a cross sectional view of the perceived adequacy of organisational procurement capacity of state and local government procurement entities (Fellows and Liu, 2008; Creswell, 2009). Similar procurement capacity assessment studies have also used the survey strategy of inquiry (Basheka, 2010; Addo-Duah et al., 2014).

\section{Design of the Survey}

The questionnaire had three main parts to address the aim of the study: 
Part 1 - Demographic Information: This captured respondents' demographic data as well as that of public agencies where they are employed. The demographic data included procurement role, experience in role, experience in procurement of infrastructure, the types of infrastructure respondents are involved in their procurement, type of respondents' organisation (i.e. state or local government agency), and location of the organisation (northern or southern geopolitical zone). Type of organisation was important to consider due to indication in the literature that there are differences in the procurement capacity of different tiers of government agencies in Nigeria (Adewole, 2014). Also, personnel working in procurement entities in different locations (north and south Nigeria) was worthy of consideration to enable a comparative exploration of the perceived adequacy of the organisational capacity of public procurement agencies in different locations.

Part 2- Adequacy of Organisational Procurement Capacity: In this part, respondents were asked to indicate their assessment of the level of adequacy of organisational procurement capacity within their organisations. Drawing from the procurement capacity literature, 23 organisational capacity items were operationalised. The items are aligned to the procurement capacity areas identified in literature (see Table 1). This was to gauge respondents perceptions of the critical gaps in the capacity of SLGAs involved in the procurement of infrastructure. A five-point Likert scale (i.e. $1=$ very inadequate; 2 = inadequate; 3 = slightly adequate; 4 = adequate; and 5 = very adequate) was used to ascertain the adequacy of the 23 organisational capacity items.

Part 3-Attainment of Procurement Objectives: This part sought to gauge respondents perceptions regarding the extent to which key procurement objectives of the PPA 2007 and modern procurement (e.g. value-for-money, transparency, accountability, competition, innovation, fairness, promotion of equality and diversity, and sustainability (Walker and Brammer, 2009; Ambe and Badenhorst-Weiss, 2012) are being met in the procurement of infrastructure by SLGAs. A five-point Likert scale (i.e. $1=$ not at all; 2 = low; 3 = moderate; 4 = high; 5 = very high) was used.

Two state locations in Nigeria were used for the inquiry: Kaduna State (in northern Nigeria) and Oyo State (in southern Nigeria). These states were selected for being homes to major cities in Nigeria (Kaduna City and Zaria in Kaduna State, and lbadan in Oyo State). According to the most recent census in Nigeria (i.e. 2006 census), the population of Kaduna State and Oyo State stand at about 6.1 million and 5.8 million, respectively (National Bureau of Statistics, 2012). Furthermore, reports have highlighted inadequate infrastructure in these states (Oyo State Government, 2010; Kaduna State Government, 2013). For instance, current water service coverage is estimated at about $23 \%$ of Kaduna State's population (Kaduna State Government, 2013) and in Oyo State it is estimated that about $17 \%$ of households have access to piped water (Ifabiyi and Ogunbode, 2014).

The survey was administered by hand delivery to personnel involved in infrastructure procurement within local government authorities' works departments, as well as within state ministries, agencies and institutions in the two locations. It was expected that such personnel would include a range of built environment and procurement personnel 
(e.g. urban/town planners, architects, civil/structural engineers, quantity surveyors, project managers, electrical engineers, and personnel acting in the capacities of project sponsors, senior responsible owners and investment decision makers) who are often involved in the initiation, planning, design/specification, execution, and evaluation phases of infrastructure procurement.

Considering the unreliability of the postal system in Nigeria to facilitate questionnaire administration, and foreseeable logistical difficulties in trying to access procurement personnel in the two states so as to solicit for their participation, the researchers adopted a pragmatic sampling approach whereby: 1) they focussed on public infrastructure procurement institutions within the major cities in the two states (i.e. Ibadan in Oyo State, and Kaduna City and Zaria in Kaduna State); and 2) relied on local knowledge and networks in the study locations to draw up a list of potential public procurement entities (including local government agencies, state ministries, and other public organisations) to be approached for participation. As previously mentioned, these cities were chosen for being major cities within their respective states. Kaduna City (also called Kaduna) is the capital city of Kaduna State and Ibadan is the capital city for Oyo State. Based on the most recent census in Nigeria (i.e. 2006), all the cities are amongst the most populous cities within their states.

To ensure validity and reliability of the primary data, aside developing the questionnaire items (e.g. the procurement capacity items) based on relevant procurement capacity literature (summarised by Table 1), the targeted responded were public procurement personnel who are involved in the procurement of infrastructure, and this meant that the responses to the questionnaire would be relevant to the study and could therefore be deem as being a credible representation of reality. Additionally, the questionnaire was initially piloted in the two states in the north and south to ensure that the target respondents would be able to easily understand the questionnaire and provide responses. The pilot involved administration of 44 questionnaires by hand delivery and collection to public procurement personnel comprising: 30 questionnaires in a public organisation (an educational institution) in the north; and 14 questionnaires in two government ministries in the south. Overall, the pilot revealed that the personnel were able to easily comprehend and complete the questionnaire. Additionally, it yielded a very favourable response rate (i.e. $84 \%$ ), which showed that the hand delivery and collection approach of questionnaire administration was effective.

Overall, 373 questionnaires were administered to public procurement personnel nested across 28 public organisations that are involved in infrastructure procurement in Kaduna State and Oyo State. The questionnaires were administered and retrieved by hand delivery and collection due to its effectiveness from the pilot administration. Following screening of the retrieved questionnaires and missing data analysis, seven questionnaires were excluded due to: 1) excessive missing data; and 2) the respondents having indicated that they had no experience in infrastructure procurement. This procedure was necessary to ensure credibility of the data and consequently the results. Table 2 shows the effective sample sizes and response rates. 


\section{Data Analyses}

IBM SPSS Statistic 23 software was used to undertake descriptive statistical analyses (e.g. frequencies, mean and standard deviation) and inferential statistical analyses. The inferential analyses were one-sample t-test and independent samples t-test. The one-sample t-test was conducted on the responses to Part 2 and 3 of the questionnaire. For example, for the Part 2 responses, the one-sample t-test (with test value of 3.5) was used to determine the critical capacity items having limited adequacy. From the five-point Likert scale, a test value of 3.5 approximates to 4 on the scale (i.e. "adequate" capacity). The adequacy of a capacity item was thus determined based on the item achieving a statistically significant Mean greater than the test value (Ahadzie et al., 2008; Field, 2013), in order words the item is perceived to be at least "adequate". The independent samples t-test was also conducted on the responses to Part 2 and 3 of the questionnaire. For example, for the Part 2 responses, the test was used to ascertain differences in the perceived adequacy of organisational capacity by two group comparisons: (1) perceptions by respondents in state organisations in comparison with those in local government organisations; and (2) perceptions by respondents in organisations in the north in comparison with those in the south.

\section{Findings}

The findings of the data analyses are given below under three main sections: demographic information; organisational capacity deficiencies; and level of attainment of procurement objectives.

\section{Demographic Information}

The roles of the respondents are: engineer $(35.07 \%)$, quantity surveyor $(12.85 \%)$, administrator (12.85\%), architect $(8.33 \%)$, builder $(8.33 \%)$, estate surveyor $(5.21 \%)$, urban/town planner (4.86\%), procurement officer/personnel (4.17\%), land surveyor $(1.04 \%)$, purchasing officer/personnel $(1.04 \%)$, and other roles $(6.25 \%)$. The other roles include geologist, engineering technologist, hydrologist, accountant, agriculturist, and environmental health officer. The majority of respondents (approximately 83\%) have been in their roles for over 5 years. The Mean experience in role is 13.48 (standard deviation $=7.21$ ). The majority of respondents (approximately 66\%) have over 5 years of experience in the procurement of infrastructure. The Mean experience (years) in procurement of infrastructure is 9.51 (standard deviation $=6.166$ ). The respondents are involved in the procurement of housing infrastructure $(37.85 \%)$, power generation and electricity infrastructure (26.04\%), education infrastructure $(23.26 \%)$, transport infrastructure $(19.79 \%)$, water and sanitation infrastructure $(15.97 \%)$, and health infrastructure $(7.29 \%)$. About $52 \%$ of the respondents are within local government institutions and $48 \%$ are within state government institutions. About $59 \%$ of the respondents are in institutions in the south, whereas approximately $41 \%$ are in the north.

\section{Organisational Capacity Deficiencies}

The survey ascertained respondents' perceptions regarding the adequacy of 23 organisational capacity items. A one-sample t-test was conducted and the results are shown in Table 3. From Table 3, none of the capacity items is deemed adequate. The only capacity item that came close to being considered adequate is "Leadership and top management support for procurement" (Mean $(M)=3.597, p=0.062)$. 
A comparison (based on independent-samples t-test) between the perceptions of respondents in state organisations and those in local government organisations about the adequacy of procurement capacity is provided by Table 4 . For the sake of brevity only the significant results (i.e. $p$-value $\leq 0.05$ ) are shown. Although Table 3 shows that none of the capacity items is generally deemed "adequate", from Table 4, the level of adequacy of the following items is perceived to be significantly better in local government organisations than in state government organisations: Effective human resource management of procurement staff $[\mathrm{t}(285)=3.336, p=0.001]$; Training and effective procurement personnel capacity development [t $(286)=4.230, p<0.001$ ]; Highly motivated and satisfied procurement staff $[\mathrm{t}(286)=4.456, p<0.001]$; Well remunerated /compensated procurement staff $[\mathrm{t}(286)=4.221, p<0.001]$; Computing and ICT facilities [t $\mathrm{t} 286)=2.262, p=0.024]$; Application of sustainability principles in procurement (e.g. in specifications, tender selection criteria etc.) [t $(286)=2.006, p=$ 0.046]; Capacity to self-finance projects (e.g. internally generated funds or public/private partnerships) [t $(286)=2.950, p=0.003]$; Capacity to meet project payment obligations on time [t $(286)=2.684, p=0.008]$; availability of Physical and logistical resources that support procurement (e.g. means of transport, office space etc.) $[\mathrm{t}(285.883)=3.010, p=0.003$ ]; Capacity for long term planning and allocation of funds for procurement [t $(286)=3.199, p=0.002]$; and Existence of policies aimed at promoting social or environmentally responsible procurement [t $(283.372)=1.999, p$ $=0.047]$. None of the organisational procurement capacity items is perceived to be significantly better in state organisations than in local government organisations.

A comparison between the perceptions of respondents based in southern organisations and those in northern organisations about the adequacy of capacity is provided by Table 5. For the sake of conciseness only the significant results (i.e. $p$ value $\leq 0.05$ ) are shown. From Table 5, there are differences in the perceived level of adequacy of four (out of the 23) capacity items: Dialogue with civil society and stakeholders [t $(242.440)=2.330, p=0.021]$; Application of sanctions for noncompliance [t $(284)=2.235, p=0.026]$; Effective procurement auditing procedures [t $(285)=2.014, p=0.045]$; and Training and effective procurement personnel capacity development $[\mathrm{t}(286)=2.277, p=0.023]$. The four capacity items are perceived to be significantly better in southern organisations than in northern organisations.

[Insert Table 3]

[Insert Table 4]

[Insert Table 5]

[Insert Table 6]

[Insert Table 7]

[Insert Table 8] 
Level of Attainment of Procurement Objectives

Respondents were asked to gauge the extent to which their organisations are achieving 14 procurement objectives drawn from the PPA 2007 and the extant literature (Walker and Brammer, 2009; Ambe and Badenhorst-Weiss, 2012). Onesample t-test was used to determine the level of attainment of the procurement objectives. Like the previous test, a test value of 3.5 was specified in order to ascertain objectives that are perceived as being attained to at least a "high" extent i.e. objectives with a Mean score significantly greater than the test value of 3.5 (Ahadzie et al., 2008). The results are shown by Table 6 . From Table 6 only Professionalism $(\mathrm{M}=3.652, \mathrm{p}$ $=0.004)$ is perceived as being attained to a high degree.

A comparison (based on independent-samples t-test) between the perceptions of respondents in state organisations and those in local government organisations regarding the level of attainment of the procurement objectives is provided by Table 7 . The results show no significant difference, suggesting that the level of attainment of the procurement objectives is not different between state institutions and local government institutions.

A comparison between the perceptions of respondents based in southern organisations and those in northern organisations regarding the level of attainment of the procurement objectives by their organisations is provided in Table 8 . From Table 8 , there are differences in the perceived level of attainment of 4 (out of the 14) procurement objectives: Compliance [t $(285)=2.394, p=0.017$ ]; Promotion of equality, diversity and opportunity (e.g. for SMEs, marginalised groups in society etc.) [t $(284)=2.733, p=0.007]$; Innovation [t $(283)=3.437, p=0.001]$; and Environmental protection [t $(285)=2.392, p=0.017$ ]. The four objectives are perceived to be significantly better in southern organisations than in northern organisations.

\section{Discussion}

Regarding adequacy of organisational procurement capacity, the findings signal acute deficiencies in the procurement capacity of SLGAs involved in infrastructure procurement, especially within the study locations, as none of the capacity items is considered "adequate". While the findings reflect previous reports (World Bank, 1995, 2000, 2003, 2013; BMPIU, 2005; Fayomi, 2013), they underscore the diminished status of procurement capacity of public procurement entities within the state and local governance structure in Nigeria. Regarding the attainment of procurement objectives by organisations, the findings also suggest that among SLGAs there is generally not a high attainment of procurement objectives. The diminished attainment of procurement objectives is corroborated by the diminished outlook of the adequacy of the organisational procurement capacity items that were examined in this research. This further highlights that, there remains an acute need for improving procurement capacity among SLGAs involved in infrastructure procurement. Professionalism is considered the only objective being attained to at least a "high" extent. This is a positive departure from the World Bank (2000) report, which identified lack of professionalism in the execution of procurement functions to be one of the challenges in public procurement in Nigeria.

Intriguingly, none of the organisational procurement capacity items was perceived to be significantly better within state than in local government organisations. On the contrary, 11 of the organisational procurement capacity items are perceived to be 
significantly better within local than in state government organisations. A further intriguing revelation is the lack of significant differences in the perceived level of attainment of objectives between state and local government organisations. Though these revelations support propositions for decentralisation of procurement to lower tiers of government to aid more effective management of public sector infrastructure provision in Nigeria (Agu and Onodugo, 2009), the revelations run counter to the notion that capacity constraints are more pronounced further down the levels of government (Adewole, 2014). The findings, thus, suggest that there could be some advantages in devolution of procurement functions further downstream the levels of government.

Regarding locational comparison of perceived adequacy of organisational procurement capacity and the level of attainment of procurement objectives, the results show that in four capacity items and four procurement objectives, the organisations in the south are relatively better than those in the North (as shown by Tables 5 and 8 ), although overall there is diminished capacity and attainment of objectives (as shown by Tables 3 and 6). This suggests that public procurement organisations in southern Nigeria may be relatively better than their northern counterparts in terms of procurement capacity. This could be a reflection of the state of socio-economic development in Nigeria, where socio-economic development (e.g. indicated by poverty levels) in the southern geopolitical zone is relatively better than in the northern geopolitical zone (National Bureau of Statistics, 2012).

\section{Implications of Findings}

Overall, the above research findings provide capacity-development insights within the Nigerian context that should be leveraged by public institutions involved in infrastructure procurement to implement reforms that would augment the procurement capacity of SLGAs. In line with this, the following implications are offered:

- Policy makers at state and local government levels and/or the relevant leaders/heads/managers of public procurement entities should formulate procurement capacity development plan(s) covering appropriate short and long-term capacity development goals and clear performance measures to guide implementation of capacity building initiatives that will address the aspects of capacity deficiency within public procurement agencies. Such plans would have to take cognisance of potential capacity differences by the level/type of organisation and the geopolitical location of the organisation.

- To facilitate actual implementation of the plans, the plans need to be cascaded down into structured and well-resourced operational elements with appropriate initiatives that will address the set performance measures. For instance, there should be periodic organisational capacity audits within state and local government public procurement entities in order for them to have up-to-date and clear indications of their capacity. To foster inter-organisational learning, the capacity audits could include peer evaluation whereby a procurement entity with similar or different characteristics (e.g. location, the types of infrastructure procured, and type of entity i.e. local government or state government) offers constructive evaluation of another procurement entity. 
- Though the study is based on data from two locales in Nigeria, it can offer useful insights for other state locales in Nigeria, and indeed other developing countries, especially within sub-Saharan Africa (SSA) where several countries (including Nigeria) have been implementing public procurement reforms (Ndercaj and Ringwald, 2014). For instance, the procurement capacity items and objectives operationalised in this study could serve as a useful outline for studying organisational capacity deficiencies among public organisations in other locales. Aligned to this, there is the need for further studies in other state locations within Nigeria in order to gain a broader view of the procurement capacity profile of public agencies that are involved in public procurement. Similar studies in other countries within the SSA region should be conducted in order to provide evidence to drive public procurement reforms in those countries. As procurement capacity is not static but dynamic (i.e. it can improve or get worse over time) such studies or assessments should be undertaken periodically in order to get an up-date view of the status of procurement capacity so as to inform appropriate capacity building initiatives as part of public procurement reforms.

\section{Conclusions}

This study has examined the capacity deficiencies of public agencies involved in the procurement of public infrastructure in Nigeria. The study has shown that there are acute deficiencies in the capacity of SLGAs (within northern and southern geopolitical zones of Nigeria) that are involved in the procurement of infrastructure. Furthermore, the attainment of procurement objectives by these agencies is low. Though the type of public organisation (i.e. state level or local government level) seem to be related to the adequacy of organisational procurement capacity, it does not seem to be related to the attainment of procurement objectives. Furthermore, the location of SLGAs that are involved in infrastructure procurement seem to be related to the adequacy of some organisational procurement capacity items as well as the attainment of some procurement objectives. Overall, these outcomes provide insights that should to be leveraged by state and local government policy makers and relevant leaders/managers of public procurement institutions to implement reforms that would continuously augment the capacity of SLGAs in Nigeria.

While useful inferences could be drawn from the findings of this study for other locations (within and outside Nigeria), the execution of the study, in particular the operationalised items could serve as an important blueprint for the empirical assessment of the infrastructure procurement capacity of public bodies in other developing countries, especially within SSA where several countries have been implementing public procurement reforms.

\section{References}

Addo-Duah, P., Westcott, T., Mason, J., Booth, C.A., and Mahamadu, A. (2014), "Developing capability of public sector procurement in Ghana: An assessment of the road subsector client" in Proceedings of Construction Research Congress 2014, 19-21 May 2014, Atlanta, Georgia, USA. American Society of Civil Engineers.

Adewole, A. (2014), "Governance reform and the challenge of implementing public procurement law regime across Nigerian state and local governments", 
International Journal of Public Administration and Management Research, Vol. 2 No. 4, pp. 25-32.

AfDB (2013), "The Infrastructure Action Plan for Nigeria: Closing the Infrastructure Gap and Accelerating Economic Transformation: Summary Report", African Development Bank (AfDB), available at: http://www.afdb.org/fileadmin/uploads/afdb/Documents/Project-and-

Operations/An_Infrastructure_Action_Plan_for_Nigeria_-

Closing_the_Infrastructure_Gap_and_Accelerating_Economic_Transformation.p df (Access 1st March 2016).

Agu, C. and Onodugo, V. A. (2009), "Infrastructure services decentralisation for poverty reduction: Nigerian states", Journal of Infrastructure Development, Vol. 1 No. 2, pp. 153-178.

Ahadzie, D. K., Proverbs, D. G., and Olomolaiye, P.O. (2008), "Critical success criteria for mass house building projects in developing countries", International Journal of Project Management, Vol. 26 No. 6, pp. 675-687.

Aliza, A. H., Stephen, K. and Bambang, T., (2011), "The importance of project governance framework in project procurement planning", Procedia Engineering, Vol. 14, pp.1929-1937.

Ambe, I. M. and Badenhorst-Weiss, J. A. (2012), "Procurement challenges in the South African public sector", Journal of Transport and Supply Chain Management, Vol. 6 No. 1, pp. 242-261.

Basheka, B. C. (2010), "Public procurement skills requirement framework for local government system in Uganda: Perception from professionals", IPPU, available online at http://www.ippu.or.ug (Access $1^{\text {st }}$ March 2016).

BMPIU (2005) A manual on public procurement reform Programme in Nigeria, BMPIU, State House, Abuja, Nigeria.

Creswell, J.W. (2009) Research Design: Qualitative, Quantitative and Mixed Method Approaches, $3^{\text {rd }}$ edn., Sage, California.

Devece, C., Palacios, D. and Martinez-Simarro, D. (2017), "Effect of information management capability on organizational performance, Service Business, Vol 11 No. 3, pp. 563-580.

Ekumankama, O.O., Ujunwa, A., Umar, H.A. and Adamu, M.I. (2012), "Managing Urban Cities in Nigeria Efficiently by Local Councils: The Capital Market Option", Management Science and Engineering, Vol. 6 No. 4, pp. 30-41.

Fayomi, I. O. (2013), "Public procurement and due process policy in Nigeria: Thrust, prospects and challenges", Peak Journal of Social Sciences and Humanities, Vol. 1 No. 4, pp. 39-45.

Fellows, R. and Liu, A. (2008) Research methods for construction, Blackwell Publishing West Sussex.

Foster, V. and Pushak, N. (2011) Country Report - Nigeria's infrastructure: $A$ continental perspective: Africa Infrastructure Country Diagnostic (AICD), The International Bank for Reconstruction and Development/The World Bank, Washington.

Geng, Y. and Doberstein, B. (2008), "Greening government procurement in developing countries: Building capacity in China", Journal of Environmental Management, Vol. 88 No. 4, pp.932-938.

Ifabiyi, I. P. and Ogunbode, T. O. (2014), "The use of composite water poverty index in assessing water scarcity in the rural areas of Oyo State, Nigeria", An International Journal of Science and Technology, Vol. 2 No. 3, pp. 51-65. 
Jensen, E. R. K. (2009), "Procurement capacity development and its integration in a broader public administration reform: New thinking, lessons learned from innovative programmes and their potential for the strengthening of public procurement systems", Presentation delivered at the ADB High Level Forum on Public Procurement Reforms in Africa, 16-17 Nov. 2009, Tunis, UN Procurement Capacity Development Centre, available online at: http://unpcdc.org/media/132292/adb\%20speach.pdf (Access 01/03/2016).

Kaduna State Government (2013), "State development plan 2014-2018", Kaduna State Government, available online at: http://www.sparcnigeria.com/RC/files/1.1.9_Kaduna_Development_Plan_2014_2018.pdf. (Access 5th October 2016)

Mahamadu, A.-M. , Mahdjoubi, L., Booth, C., Manu, P. and Manu, E. (In press) Building Information Modelling (BIM) capability and delivery success on construction projects. Construction Innovation: Information, Process, Management. Doi: $10.1108 / \mathrm{Cl}-03-2018-0016$.

Meyer, J. (2014), "Institutional maturity model: A tool to fill gaps in measuring development of procurement systems (presentation)", The World Bank Conference on Procurement: Delivering Development Outcomes, February 19, 2014, Washington, available online at: http://www.worldbank.org/content/dam/Worldbank/Event/Meyer.pdf (access 1st March 2016).

National Bureau of Statistics (2012), "Annual abstract of statistics 2012", National Bureau of Statistics, available online at: http://www.nigerianstat.gov.ng/pdfuploads/annual_abstract_2012.pdf (Access 22nd January 2017).

Ndercaj, V. and Ringwald, K. (2014), "An Investigation into the common challenges facing public sector procurement in sub-Saharan Africa", in $6^{\text {th }}$ Public

Procurement Research Student Conference, April 28-29, Nottingham. UK.

NIAF (2016), "NIAF 2 Briefing Note", NIAF, available online at: http://niafng.org/about$2 /$ (access $26^{\text {th }}$ January 2017)

Ocheni, S. and Nwankwo, B. C. (2012), "Assessment of application of Due-Process Policy in public procurement and contracts under Obasanjo Administration in Nigeria, 2003-2007", International Business and Management, Vol 5 No.1, pp.9398.

OECD (2006), "The challenge of capacity development", Development Assistance Committee (DAC) - OECD, available online at: http://www.fao.org/fileadmin/templates/capacitybuilding/pdf/DAC_paper_final.pdf (1st March 2016).

OECD and World Bank (2004), "Good practice paper on procurement capacity development" paper presented at The OECD Development Assistance Committee (DAC) - World Bank 3rd joint round table on strengthening procurement capacities in 24 developing countries, 30 November - 2 December 2004, Johannesburg, South Africa. OECD and World Bank

Oyo State Government (2010) Strategic health development plan (2010-2015). Oyo State Government. Available online at http://www.mamaye.org.ng/sites/default/files/evidence/Oyo\%20SSHDP\%2005.01. 11.pdf (Access 28/01/2017).

Public Procurement Act 2007 (2007) Lagos: The Federal Government Printer. 
Smits, W., van Buiten, M. and Hartmann, T. (2017), "Yield-to-BIM: impacts of BIM Maturity on Project Performance", Building Research and Information, Vol 45 No. 3, pp. 336-346.

UNDP (2006) Procurement Capacity Assessment User's Guide, UNDP, New York.

UNDP (2010), "Public procurement capacity development guide", UNDP, available online

http://unpcdc.org/media/140954/procurement\%20capacity\%20assessment\%20gui de.pdf (Access $1^{\text {st }}$ March 2016).

United Nations Economic and Social Council (2016), "Progress towards the Sustainable Development Goals - Report of the Secretary-General", United Nations Economic and Social Council, available online at: https://unstats.un.org/sdgs/files/report/2016/secretary-general-sdg-report-2016-EN.pdf (Accessed 23rd March 2017).

Veitch, C. (2014), "Infrastructure Industry in Nigeria", Who owns Who (Pty), South Africa, available at: http://www.whoownswhom.co.za/public/sasector/report_content/Pages\%20from\% 20502\%20-\%20The\%20Infrastructure\%20Industry\%20Nigeria\%20$\% 20$ March\%202016\%20-\%20Contents.pdf (accesses $3^{\text {rd }}$ April 16)

Walker, H. and Brammer, S. (2009), "Sustainable procurement in the United Kingdom public sector", Supply Chain Management: An International Journal, Vol. 14 No. 2. pp. $128-137$.

World Bank (1995), "Restoring urban Nigeria a strategy for restoring urban infrastructure and services in Nigeria. Report No. 45557", World Bank, available online at: http://documents.worldbank.org/curated/en/1995/12/10735837/restoringurban-nigeria-strategy-restoring-urban-infrastructure-services-nigeria (Access 1st March 2016).

World Bank (2000), "Nigeria: Country Procurement Assessment Report (CPAR)", Vol 1. Summary of findings and recommendations, Nigeria Country Department, World Bank, available online at: http://documents.worldbank.org/curated/en/2000/06/1121258/nigeria-countryprocurement-assessment-report-cpar (accessed 1st March 2016).

World Bank (2003), "Ghana: Country Procurement Assessment Report (CPAR)", Vol 1. Executive Summary, World Bank, available online at https://openknowledge.worldbank.org/handle/10986/15638 (accessed 1st March 2016).

World Bank (2013) Nigeria Value Chain Analysis Study - A Study of Selected MDA's. World Bank Africa Report Number ACS 1666, World Bank, Washington DC. 


\begin{tabular}{|c|c|c|c|c|c|}
\hline \multirow[b]{2}{*}{ Procurement Capacity Areas } & \multicolumn{5}{|c|}{ Literature Sources } \\
\hline & 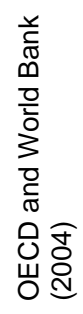 & 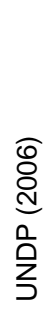 & 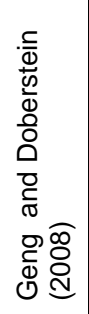 & 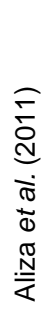 & $\begin{array}{l}\text { J } \\
\stackrel{\mathbb{N}}{\mathbf{d}} \\
\stackrel{\bar{d}}{\Sigma}\end{array}$ \\
\hline $\begin{array}{l}\text { Leadership, top management support for procurement, and strategic planning for } \\
\text { procurement. }\end{array}$ & $\sqrt{ }$ & $\sqrt{ }$ & $\sqrt{ }$ & $\sqrt{ }$ & $\sqrt{ }$ \\
\hline $\begin{array}{l}\text { Accountability and transparency mechanisms that ensure conformance to national } \\
\text { policy and legal frameworks for procurement. }\end{array}$ & $\sqrt{ }$ & $\sqrt{ }$ & $\sqrt{ }$ & $\sqrt{ }$ & \\
\hline $\begin{array}{l}\text { Public engagement including participaction of civil society organisations and } \\
\text { private sector in the public procurement process. }\end{array}$ & $\sqrt{ }$ & $\sqrt{ }$ & $\sqrt{ }$ & $\sqrt{ }$ & \\
\hline $\begin{array}{l}\text { Human resources and management e.g. skilled and qualified staff, and staff } \\
\text { development. }\end{array}$ & $\sqrt{ }$ & $\sqrt{ }$ & $\sqrt{ }$ & $\sqrt{ }$ & $\sqrt{ }$ \\
\hline $\begin{array}{l}\text { Physical and logistical resources that support procurement e.g. office/work } \\
\text { environment and information and communication technology facilities. }\end{array}$ & $\sqrt{ }$ & $\sqrt{ }$ & $\sqrt{ }$ & $\sqrt{ }$ & $\sqrt{ }$ \\
\hline $\begin{array}{l}\text { Policies and frameworks that promote socially and environmentally responsible } \\
\text { procurement. }\end{array}$ & $\sqrt{ }$ & $\sqrt{ }$ & $\sqrt{ }$ & & \\
\hline Procurement rules and procedures that incorporate lifecycle approaches. & & & $\sqrt{ }$ & & \\
\hline $\begin{array}{l}\text { Financial resources and management e.g. availability of finance and financial } \\
\text { management systems. }\end{array}$ & $\sqrt{ }$ & $\sqrt{ }$ & $\sqrt{ }$ & $\sqrt{ }$ & \\
\hline
\end{tabular}


Table 2: Response Rate

\begin{tabular}{l|c|c|c|c}
\hline Location & $\begin{array}{c}\text { Administered } \\
\text { Questionnaire to Public } \\
\text { Procurement Personnel }\end{array}$ & $\begin{array}{c}\text { Returned } \\
\text { Questionnaire }\end{array}$ & $\begin{array}{c}\text { Valid Returned } \\
\text { Questionnaire }\end{array}$ & $\begin{array}{c}\text { Effective Response } \\
\text { Rate }\end{array}$ \\
\hline Kaduna State (North) & 195 & 117 & 117 & $60.00 \%$ \\
\hline Oyo State (South) & 178 & 178 & 171 & $96.07 \%$ \\
\hline Total & 373 & 295 & 288 & $77.21 \%$ \\
\hline
\end{tabular}


Table 3: Perceived Adequacy of Organisational Procurement Capacity

\begin{tabular}{|c|c|c|c|c|c|c|c|c|c|c|c|c|}
\hline \multirow[t]{2}{*}{ Organisational Capacity Items } & \multirow[t]{2}{*}{$\mathrm{N}$} & \multirow[t]{2}{*}{ Mean } & \multirow{2}{*}{$\begin{array}{l}\text { Rank } \\
\text { by } \\
\text { Mean }\end{array}$} & \multirow{2}{*}{$\begin{array}{l}\text { Std. } \\
\text { Dev. }\end{array}$} & \multirow{2}{*}{$\begin{array}{l}\text { Std. } \\
\text { Error } \\
\text { Mean }\end{array}$} & \multicolumn{7}{|c|}{ One-Sample t-test (Test Value $=3.5$ ) } \\
\hline & & & & & & $\mathrm{t}$ & df & $\begin{array}{l}\text { Sig. } \\
(2- \\
\text { tailed })\end{array}$ & $\begin{array}{l}\text { Sig. } \\
(1- \\
\text { tailed })\end{array}$ & $\begin{array}{l}\text { Mean } \\
\text { Diff. }\end{array}$ & \multicolumn{2}{|c|}{$\begin{array}{l}95 \% \text { Confidence } \\
\text { Interval of the } \\
\text { Difference }\end{array}$} \\
\hline $\begin{array}{l}\text { Leadership and top management support for } \\
\text { procurement }\end{array}$ & 288 & 3.597 & 1 & 1.071 & 0.063 & 1.540 & 287.000 & 0.125 & 0.062 & 0.097 & -0.030 & 0.220 \\
\hline $\begin{array}{l}\text { Internal mechanisms that ensure conformance to } \\
\text { national policy and legal frameworks for procurement }\end{array}$ & 288 & 3.465 & 3 & 0.973 & 0.057 & -0.606 & 287.000 & 0.545 & 0.273 & -0.035 & -0.150 & 0.080 \\
\hline Number of qualified procurement personnel & 288 & 3.455 & 4 & 1.015 & 0.060 & -0.755 & 287.000 & 0.451 & 0.225 & -0.045 & -0.160 & 0.070 \\
\hline $\begin{array}{l}\text { Effective human resource management of procurement } \\
\text { staff }\end{array}$ & 287 & 3.436 & 5 & 0.997 & 0.059 & -1.095 & 286.000 & 0.275 & 0.137 & -0.064 & -0.180 & 0.050 \\
\hline $\begin{array}{l}\text { Capacity for long term planning and allocation of funds } \\
\text { for procurement }\end{array}$ & 288 & 3.420 & 6 & 1.085 & 0.064 & -1.249 & 287.000 & 0.213 & 0.106 & -0.080 & -0.210 & 0.050 \\
\hline Internal anti-corruption mechanisms & 288 & 3.417 & 7 & 1.046 & 0.062 & -1.352 & 287.000 & 0.177 & 0.089 & -0.083 & -0.200 & 0.040 \\
\hline Effective procurement auditing procedures & 287 & 3.387 & 8 & 1.034 & 0.061 & -1.854 & 286.000 & 0.065 & 0.032 & -0.113 & -0.230 & 0.010 \\
\hline $\begin{array}{l}\text { Application of sustainability principles in procurement } \\
\text { (e.g. in specifications, tender selection criteria etc.) }\end{array}$ & 288 & 3.365 & 9 & 0.964 & 0.057 & -2.384 & 287.000 & 0.018 & 0.009 & -0.135 & -0.250 & -0.020 \\
\hline Capacity to meet project payment obligations on time & 288 & 3.344 & 10 & 1.041 & 0.061 & -2.547 & 287.000 & 0.011 & 0.006 & -0.156 & -0.280 & -0.040 \\
\hline Computing and ICT facilities & 288 & 3.295 & 11 & 1.141 & 0.067 & -3.046 & 287.000 & 0.003 & 0.001 & -0.205 & -0.340 & -0.070 \\
\hline $\begin{array}{l}\text { Training and effective procurement personnel capacity } \\
\text { development }\end{array}$ & 288 & 3.281 & 12 & 1.056 & 0.062 & -3.514 & 287.000 & 0.001 & 0.000 & -0.219 & -0.340 & -0.100 \\
\hline
\end{tabular}


Physical and logistical resources that support

procurement (e.g. means of transport, office space etc.)

\section{Application of sanctions for non-compliance}

Highly motivated and satisfied procurement staff

Dialogue with civil society and stakeholders

Procurement rules and procedures that incorporate lifecycle approach to analysis and costing

Integration of procurement with internal financial management and budgeting systems

Inclusion and participation of civil society organisations and media in the public procurement process

Inclusion and participation of private sector institutions in procurement process

Capacity to self-finance projects (e.g. internally generated funds or public/private partnerships)

Existence of policies aimed at promoting social or environmentally responsible procurement

Well remunerated/compensated procurement staff

\begin{tabular}{|c|c|c|c|c|c|}
\hline 288 & 3.274 & 13 & 1.110 & 0.065 & -3.452 \\
\hline 286 & 3.259 & 14 & 1.044 & 0.062 & -3.907 \\
\hline 288 & 3.254 & 15 & 1.092 & 0.064 & -3.830 \\
\hline 288 & 3.240 & 16 & 1.083 & 0.064 & -4.082 \\
\hline 287 & 3.233 & 17 & 0.967 & 0.057 & -4.670 \\
\hline 288 & 3.233 & 17 & 1.078 & 0.064 & -4.210 \\
\hline 288 & 3.215 & 19 & 1.102 & 0.065 & -4.384 \\
\hline 288 & 3.212 & 20 & 1.111 & 0.065 & -4.403 \\
\hline 288 & 3.191 & 21 & 1.108 & 0.065 & -4.732 \\
\hline 288 & 3.188 & 22 & 1.008 & 0.059 & -5.259 \\
\hline 2 & 3.170 & 23 & 1.164 & 0.069 & -4.810 \\
\hline
\end{tabular}

\begin{tabular}{|c|c|c|c|c|c|}
\hline 287.000 & 0.001 & 0.000 & -0.226 & -0.350 & -0.100 \\
\hline 285.000 & 0.000 & 0.000 & -0.241 & -0.360 & -0.120 \\
\hline 287.000 & 0.000 & 0.000 & -0.247 & -0.370 & -0.120 \\
\hline 287.000 & 0.000 & 0.000 & -0.260 & -0.390 & -0.130 \\
\hline 286.000 & 0.000 & 0.000 & -0.267 & -0.380 & -0.150 \\
\hline 287.000 & 0.000 & 0.000 & -0.267 & -0.390 & -0.140 \\
\hline 287.000 & 0.000 & 0.000 & -0.285 & -0.410 & -0.160 \\
\hline 287.000 & 0.000 & 0.000 & -0.288 & -0.420 & -0.160 \\
\hline 287.000 & 0.000 & 0.000 & -0.309 & -0.440 & -0.180 \\
\hline 287.000 & 0.000 & 0.000 & -0.313 & -0.430 & -0.200 \\
\hline 287.000 & 0.000 & 0.000 & -0.330 & -0.460 & -0.190 \\
\hline
\end{tabular}


Table 4: Differences in Perceived Adequacy of Organisational Capacity - Type of Organisation

\begin{tabular}{|c|c|c|c|c|c|c|c|c|c|c|c|c|c|}
\hline \multirow[t]{2}{*}{$\begin{array}{l}\text { Organisational Procurement } \\
\text { Capacity Item }\end{array}$} & \multirow[t]{2}{*}{$\begin{array}{l}\text { Type of } \\
\text { organisation }\end{array}$} & \multirow[t]{2}{*}{$\mathrm{N}$} & \multirow[t]{2}{*}{ Mean } & \multirow[t]{2}{*}{$\begin{array}{l}\text { Std. } \\
\text { Dev. }\end{array}$} & \multirow{2}{*}{$\begin{array}{l}\text { Std. } \\
\text { Error } \\
\text { Mean }\end{array}$} & \multicolumn{3}{|c|}{$\begin{array}{c}\text { Levene's Test for Equality of } \\
\text { Variances }\end{array}$} & \multicolumn{5}{|c|}{ t-test for Equality of Means } \\
\hline & & & & & & $\begin{array}{l}\text { Equality of } \\
\text { variances }\end{array}$ & $\mathrm{F}$ & Sig. & $\mathrm{t}$ & df & $\begin{array}{l}\text { Sig. }(2- \\
\text { tailed) }\end{array}$ & $\begin{array}{c}\text { Mean } \\
\text { Diff. }\end{array}$ & $\begin{array}{l}\text { Std. } \\
\text { Error } \\
\text { Diff. }\end{array}$ \\
\hline $\begin{array}{l}\text { Effective human resource } \\
\text { management of } \\
\text { procurement staff }\end{array}$ & $\begin{array}{l}\text { Local government } \\
\text { State government }\end{array}$ & $\begin{array}{l}150 \\
137\end{array}$ & $\begin{array}{l}3.6200 \\
3.2336\end{array}$ & $\begin{array}{l}0.974 \\
0.987\end{array}$ & $\begin{array}{l}0.080 \\
0.084\end{array}$ & \begin{tabular}{|l|} 
Equal \\
variances \\
assumed \\
Equal \\
variances not \\
assumed \\
\end{tabular} & 0.107 & 0.743 & $\begin{array}{l}3.336 \\
3.334\end{array}$ & $\begin{array}{l}285.000 \\
281.925\end{array}$ & $\begin{array}{l}0.001 \\
0.001\end{array}$ & $\begin{array}{l}0.386 \\
0.386\end{array}$ & $\begin{array}{l}0.116 \\
0.116\end{array}$ \\
\hline $\begin{array}{l}\text { Training and effective } \\
\text { procurement personnel } \\
\text { capacity development }\end{array}$ & $\begin{array}{l}\text { Local government } \\
\text { State government }\end{array}$ & $\begin{array}{l}150 \\
138\end{array}$ & $\begin{array}{l}3.5267 \\
3.0145\end{array}$ & $\begin{array}{l}1.034 \\
1.018\end{array}$ & $\begin{array}{l}0.084 \\
0.087\end{array}$ & \begin{tabular}{|l|} 
Equal \\
variances \\
assumed \\
Equal \\
variances not \\
assumed
\end{tabular} & 1.423 & 0.234 & $\begin{array}{l}4.230 \\
4.233\end{array}$ & $\begin{array}{l}286.000 \\
284.691\end{array}$ & $\begin{array}{l}0.000 \\
0.000\end{array}$ & $\begin{array}{l}0.512 \\
0.512\end{array}$ & $\begin{array}{l}0.121 \\
0.121\end{array}$ \\
\hline $\begin{array}{l}\text { Highly motivated and } \\
\text { satisfied procurement staff }\end{array}$ & $\begin{array}{l}\text { Local government } \\
\text { State government }\end{array}$ & $\begin{array}{l}150 \\
138\end{array}$ & $\begin{array}{l}3.5200 \\
2.9638\end{array}$ & $\begin{array}{l}1.028 \\
1.090\end{array}$ & $\begin{array}{l}0.084 \\
0.093\end{array}$ & \begin{tabular}{|l|} 
Equal \\
variances \\
assumed \\
Equal \\
variances not \\
assumed \\
\end{tabular} & 0.000 & 0.984 & $\begin{array}{l}4.456 \\
4.445\end{array}$ & $\begin{array}{l}286.000 \\
280.330\end{array}$ & $\begin{array}{l}0.000 \\
0.000\end{array}$ & $\begin{array}{l}0.556 \\
0.556\end{array}$ & $\begin{array}{l}0.125 \\
0.125\end{array}$ \\
\hline $\begin{array}{l}\text { Well remunerated } \\
\text { /compensated procurement } \\
\text { staff }\end{array}$ & $\begin{array}{l}\text { Local government } \\
\text { State government }\end{array}$ & $\begin{array}{l}150 \\
138\end{array}$ & $\begin{array}{l}3.4400 \\
2.8768\end{array}$ & $\begin{array}{l}1.161 \\
1.097\end{array}$ & $\begin{array}{l}0.095 \\
0.093\end{array}$ & \begin{tabular}{|l|} 
Equal \\
variances \\
assumed \\
Equal \\
variances not \\
assumed \\
\end{tabular} & 2.061 & 0.152 & $\begin{array}{l}4.221 \\
4.232\end{array}$ & $\begin{array}{l}286.000 \\
285.795\end{array}$ & $\begin{array}{l}0.000 \\
0.000\end{array}$ & $\begin{array}{l}0.563 \\
0.563\end{array}$ & $\begin{array}{l}0.133 \\
0.133\end{array}$ \\
\hline $\begin{array}{l}\text { Physical and logistical } \\
\text { resources that support } \\
\text { procurement (e.g. means of } \\
\text { transport, office space etc.) }\end{array}$ & $\begin{array}{l}\text { Local government } \\
\text { State government }\end{array}$ & $\begin{array}{l}150 \\
138\end{array}$ & $\begin{array}{l}3.4600 \\
3.0725\end{array}$ & $\begin{array}{l}1.127 \\
1.058\end{array}$ & $\begin{array}{l}0.092 \\
0.090\end{array}$ & \begin{tabular}{|l|} 
Equal \\
variances \\
assumed \\
Equal \\
variances not \\
assumed
\end{tabular} & 4.290 & 0.039 & 3.002 & $\begin{array}{l}286.000 \\
285.883\end{array}$ & $\begin{array}{l}0.003 \\
0.003\end{array}$ & $\begin{array}{l}0.388 \\
0.388\end{array}$ & $\begin{array}{l}0.129 \\
0.129\end{array}$ \\
\hline Computing and ICT facilities & $\begin{array}{l}\text { Local government } \\
\text { State government }\end{array}$ & $\begin{array}{l}150 \\
138\end{array}$ & $\begin{array}{l}3.4400 \\
3.1377\end{array}$ & $\begin{array}{l}1.144 \\
1.122\end{array}$ & $\begin{array}{l}0.093 \\
0.095\end{array}$ & \begin{tabular}{|l|} 
Equal \\
variances \\
assumed \\
Equal \\
variances not \\
assumed
\end{tabular} & 0.783 & 0.377 & $\begin{array}{l}2.262 \\
2.263\end{array}$ & $\begin{array}{l}286.000 \\
284.828\end{array}$ & $\begin{array}{l}0.024 \\
0.024\end{array}$ & $\begin{array}{l}0.302 \\
0.302\end{array}$ & $\begin{array}{l}0.134 \\
0.134\end{array}$ \\
\hline
\end{tabular}




\begin{tabular}{|c|c|c|c|c|c|c|c|c|c|c|c|c|c|}
\hline $\begin{array}{l}\text { Application of sustainability } \\
\text { principles in procurement } \\
\text { (e.g. in specifications, tender } \\
\text { selection criteria etc.) }\end{array}$ & $\begin{array}{l}\text { Local government } \\
\text { State government }\end{array}$ & $\begin{array}{l}150 \\
138\end{array}$ & $\begin{array}{l}3.4733 \\
3.2464\end{array}$ & $\begin{array}{l}0.946 \\
0.973\end{array}$ & $\begin{array}{l}0.077 \\
0.083\end{array}$ & $\begin{array}{l}\text { Equal } \\
\text { variances } \\
\text { assumed } \\
\text { Equal } \\
\text { variances not } \\
\text { assumed }\end{array}$ & 0.012 & 0.914 & $\begin{array}{l}2.006 \\
2.004\end{array}$ & $\begin{array}{l}286.000 \\
282.502\end{array}$ & $\begin{array}{l}0.046 \\
0.046\end{array}$ & $\begin{array}{l}0.227 \\
0.227\end{array}$ & $\begin{array}{l}0.113 \\
0.113\end{array}$ \\
\hline $\begin{array}{l}\text { Existence of policies aimed } \\
\text { at promoting social or } \\
\text { environmentally responsible } \\
\text { procurement }\end{array}$ & $\begin{array}{l}\text { Local government } \\
\text { State government }\end{array}$ & $\begin{array}{l}150 \\
138\end{array}$ & $\begin{array}{l}3.3000 \\
3.0652\end{array}$ & $\begin{array}{l}1.085 \\
0.906\end{array}$ & $\begin{array}{l}0.089 \\
0.077\end{array}$ & $\begin{array}{l}\text { Equal } \\
\text { variances } \\
\text { assumed } \\
\text { Equal } \\
\text { variances not } \\
\text { assumed } \\
\end{array}$ & 10.535 & 0.001 & $\begin{array}{l}1.984 \\
1.999\end{array}$ & $\begin{array}{l}286.000 \\
283.372\end{array}$ & $\begin{array}{l}0.048 \\
0.047\end{array}$ & $\begin{array}{l}0.235 \\
0.235\end{array}$ & $\begin{array}{l}0.118 \\
0.117\end{array}$ \\
\hline $\begin{array}{l}\text { Capacity to self-finance } \\
\text { projects (e.g. internally } \\
\text { generated funds or } \\
\text { public/private partnerships) }\end{array}$ & $\begin{array}{l}\text { Local government } \\
\text { State government }\end{array}$ & $\begin{array}{l}150 \\
138\end{array}$ & $\begin{array}{l}3.3733 \\
2.9928\end{array}$ & $\begin{array}{l}1.102 \\
1.084\end{array}$ & $\begin{array}{l}0.090 \\
0.092\end{array}$ & $\begin{array}{l}\text { Equal } \\
\text { variances } \\
\text { assumed } \\
\text { Equal } \\
\text { variances not } \\
\text { assumed }\end{array}$ & 1.640 & 0.201 & $\begin{array}{l}2.950 \\
2.952\end{array}$ & $\begin{array}{l}286.000 \\
284.727\end{array}$ & $\begin{array}{l}0.003 \\
0.003\end{array}$ & $\begin{array}{l}0.381 \\
0.381\end{array}$ & $\begin{array}{l}0.129 \\
0.129\end{array}$ \\
\hline $\begin{array}{l}\text { Capacity to meet project } \\
\text { payment obligations on time }\end{array}$ & $\begin{array}{l}\text { Local government } \\
\text { State government }\end{array}$ & $\begin{array}{l}150 \\
138\end{array}$ & $\begin{array}{l}3.5000 \\
3.1739\end{array}$ & $\begin{array}{l}1.041 \\
1.017\end{array}$ & $\begin{array}{l}0.085 \\
0.087\end{array}$ & $\begin{array}{l}\text { Equal } \\
\text { variances } \\
\text { assumed } \\
\text { Equal } \\
\text { variances not } \\
\text { assumed } \\
\end{array}$ & 0.414 & 0.521 & $\begin{array}{l}2.684 \\
2.687\end{array}$ & $\begin{array}{l}286.000 \\
284.949\end{array}$ & $\begin{array}{l}0.008 \\
0.008\end{array}$ & $\begin{array}{l}0.326 \\
0.326\end{array}$ & $\begin{array}{l}0.121 \\
0.121\end{array}$ \\
\hline $\begin{array}{l}\text { Capacity for long term } \\
\text { planning and allocation of } \\
\text { funds for procurement }\end{array}$ & $\begin{array}{l}\text { Local government } \\
\text { State government }\end{array}$ & $\begin{array}{l}150 \\
138\end{array}$ & $\begin{array}{l}3.6133 \\
3.2101\end{array}$ & $\begin{array}{l}1.086 \\
1.050\end{array}$ & $\begin{array}{l}0.089 \\
0.089\end{array}$ & $\begin{array}{l}\text { Equal } \\
\text { variances } \\
\text { assumed } \\
\text { Equal } \\
\text { variances not } \\
\text { assumed }\end{array}$ & 0.756 & 0.385 & $\begin{array}{l}3.199 \\
3.204\end{array}$ & $\begin{array}{l}286.000 \\
285.287\end{array}$ & $\begin{array}{l}0.002 \\
0.002\end{array}$ & $\begin{array}{l}0.403 \\
0.403\end{array}$ & $\begin{array}{l}0.126 \\
0.126\end{array}$ \\
\hline
\end{tabular}

Note: Scale: 1 = very inadequate; 2 = inadequate; 3 = slightly adequate; 4 = adequate; 5 = very adequate 
Table 5: Differences in Perceived Adequacy of Organisational Capacity - By Location

\begin{tabular}{|c|c|c|c|c|c|c|c|c|c|c|c|c|c|}
\hline \multirow{2}{*}{$\begin{array}{l}\text { Organisational Procurement } \\
\text { Capacity Item }\end{array}$} & \multirow[t]{2}{*}{ Location } & \multirow[t]{2}{*}{$\mathrm{N}$} & \multirow[t]{2}{*}{ Mean } & \multirow{2}{*}{$\begin{array}{l}\text { Std. } \\
\text { Dev. }\end{array}$} & \multirow{2}{*}{$\begin{array}{l}\text { Std. } \\
\text { Error } \\
\text { Mean }\end{array}$} & \multicolumn{3}{|c|}{ Levene's Test for Equality of Variances } & \multicolumn{5}{|c|}{ t-test for Equality of Means } \\
\hline & & & & & & Equality of Variances & $\mathrm{F}$ & Sig. & $\mathrm{t}$ & df & $\begin{array}{l}\text { Sig. (2- } \\
\text { tailed) }\end{array}$ & $\begin{array}{l}\text { Mean } \\
\text { Diff. }\end{array}$ & $\begin{array}{l}\text { Std. } \\
\text { Error } \\
\text { Diff. }\end{array}$ \\
\hline \multirow{2}{*}{$\begin{array}{l}\text { Dialogue with civil society and } \\
\text { stakeholders }\end{array}$} & South & 171 & 3.363 & 1.056 & 0.081 & $\begin{array}{l}\text { Equal variances } \\
\text { assumed }\end{array}$ & 0.040 & 0.841 & 2.349 & 286.000 & 0.020 & 0.303 & 0.129 \\
\hline & North & 117 & 3.060 & 1.101 & 0.102 & $\begin{array}{l}\text { Equal variances not } \\
\text { assumed }\end{array}$ & & & 2.330 & 242.440 & 0.021 & 0.303 & 0.130 \\
\hline \multirow{2}{*}{$\begin{array}{l}\text { Application of sanctions for } \\
\text { non-compliance }\end{array}$} & South & 169 & 3.373 & 1.034 & 0.080 & $\begin{array}{l}\text { Equal variances } \\
\text { assumed }\end{array}$ & 0.505 & 0.478 & 2.235 & 284.000 & 0.026 & 0.279 & 0.125 \\
\hline & North & 117 & 3.094 & 1.042 & 0.096 & $\begin{array}{l}\text { Equal variances not } \\
\text { assumed }\end{array}$ & & & 2.232 & 248.311 & 0.027 & 0.279 & 0.125 \\
\hline \multirow{2}{*}{$\begin{array}{l}\text { Effective procurement auditing } \\
\text { procedures }\end{array}$} & South & 170 & 3.488 & 1.004 & 0.077 & $\begin{array}{l}\text { Equal variances } \\
\text { assumed }\end{array}$ & 0.159 & 0.690 & 2.014 & 285.000 & 0.045 & 0.249 & 0.124 \\
\hline & North & 117 & 3.239 & 1.064 & 0.098 & $\begin{array}{l}\text { Equal variances not } \\
\text { assumed }\end{array}$ & & & 1.992 & 239.972 & 0.047 & 0.249 & 0.125 \\
\hline \multirow{2}{*}{$\begin{array}{l}\text { Training and effective } \\
\text { procurement personnel } \\
\text { capacity development }\end{array}$} & South & 171 & 3.398 & 1.065 & 0.081 & $\begin{array}{l}\text { Equal variances } \\
\text { assumed }\end{array}$ & 1.175 & 0.279 & 2.277 & 286.000 & 0.023 & 0.287 & 0.126 \\
\hline & North & 117 & 3.111 & 1.024 & 0.095 & $\begin{array}{l}\text { Equal variances not } \\
\text { assumed }\end{array}$ & & & 2.295 & 255.788 & 0.023 & 0.287 & 0.125 \\
\hline
\end{tabular}

Note: Scale: $1=$ very inadequate; $2=$ inadequate; $3=$ slightly adequate; $4=$ adequate; $5=$ very adequate 
Table 6: Perceived Level of Attainment of Procurement Objectives

\begin{tabular}{|c|c|c|c|c|c|c|c|c|c|c|c|c|}
\hline \multirow[t]{3}{*}{ Procurement Objectives } & \multirow[t]{3}{*}{$\mathrm{N}$} & \multirow[t]{3}{*}{ Mean } & \multirow{3}{*}{$\begin{array}{l}\text { Rank } \\
\text { by } \\
\text { Mean }\end{array}$} & \multirow{3}{*}{$\begin{array}{l}\text { Std. } \\
\text { Dev. }\end{array}$} & \multirow{3}{*}{$\begin{array}{l}\text { Std. } \\
\text { Error } \\
\text { Mean }\end{array}$} & \multicolumn{7}{|c|}{ One-Sample t-test (Test Value $=3.5$ ) } \\
\hline & & & & & & \multirow[t]{2}{*}{$\mathrm{t}$} & \multirow[t]{2}{*}{ df } & \multirow[t]{2}{*}{$\begin{array}{l}\text { Sig. } \\
(2- \\
\text { tailed })\end{array}$} & \multirow[t]{2}{*}{$\begin{array}{l}\text { Sig. } \\
(1- \\
\text { tailed })\end{array}$} & \multirow[t]{2}{*}{$\begin{array}{l}\text { Mean } \\
\text { Diff. }\end{array}$} & \multicolumn{2}{|c|}{$\begin{array}{c}95 \% \text { Confidence } \\
\text { Interval of the } \\
\text { Difference } \\
\end{array}$} \\
\hline & & & & & & & & & & & Lower & Upper \\
\hline${ }^{\text {a Professionalism }}$ & 287 & 3.652 & 1 & 0.948 & 0.056 & 2.708 & 286.000 & 0.007 & 0.004 & 0.152 & 0.040 & 0.260 \\
\hline Accountability & 287 & 3.526 & 2 & 0.967 & 0.057 & 0.458 & 286.000 & 0.648 & 0.324 & 0.026 & -0.090 & 0.140 \\
\hline Value-for-money & 287 & 3.512 & 3 & 0.934 & 0.055 & 0.221 & 286.000 & 0.825 & 0.413 & 0.012 & -0.100 & 0.120 \\
\hline Cost effectiveness & 287 & 3.463 & 4 & 0.937 & 0.055 & -0.661 & 286.000 & 0.509 & 0.255 & -0.037 & -0.150 & 0.070 \\
\hline Standardisation of procurement procedures & 287 & 3.46 & 5 & 0.941 & 0.056 & -0.721 & 286.000 & 0.471 & 0.236 & -0.040 & -0.150 & 0.070 \\
\hline Environmental protection & 287 & 3.439 & 6 & 1.082 & 0.064 & -0.955 & 286.000 & 0.340 & 0.170 & -0.061 & -0.190 & 0.060 \\
\hline Transparency & 288 & 3.42 & 7 & 0.992 & 0.058 & -1.367 & 287.000 & 0.173 & 0.086 & -0.080 & -0.190 & 0.040 \\
\hline Compliance & 287 & 3.39 & 8 & 0.893 & 0.053 & -2.081 & 286.000 & 0.038 & 0.019 & -0.110 & -0.210 & -0.010 \\
\hline Fairness & 286 & 3.367 & 9 & 0.963 & 0.057 & -2.333 & 285.000 & 0.020 & 0.010 & -0.133 & -0.240 & -0.020 \\
\hline Sustainability & 287 & 3.317 & 10 & 0.943 & 0.056 & -3.287 & 286.000 & 0.001 & 0.001 & -0.183 & -0.290 & -0.070 \\
\hline Competition in procurement process & 287 & 3.23 & 11 & 1.049 & 0.062 & -4.360 & 286.000 & 0.000 & 0.000 & -0.270 & -0.390 & -0.150 \\
\hline $\begin{array}{l}\text { Promotion of equality, diversity and opportunity (e.g. for SMEs, } \\
\text { marginalised groups in society etc.) }\end{array}$ & 286 & 3.213 & 12 & 0.977 & 0.058 & -4.963 & 285.000 & 0.000 & 0.000 & -0.287 & -0.400 & -0.170 \\
\hline Innovation & 285 & 3.2 & 13 & 0.978 & 0.058 & -5.179 & 284.000 & 0.000 & 0.000 & -0.300 & -0.410 & -0.190 \\
\hline Private sector participation & 287 & 3.031 & 14 & 1.039 & 0.061 & -7.642 & 286.000 & 0.000 & 0.000 & -0.469 & -0.590 & -0.350 \\
\hline
\end{tabular}

Note: Scale: 1 = not at all; 2 = low; 3 = moderate; 4 = high; $5=$ very high

a Objectives for which Mean score is significantly greater than 3.5 . 
Table 7: Differences in Perceived Level of Attainment of Procurement Objectives - By Type of Organisation

\begin{tabular}{|c|c|c|c|c|c|c|c|c|c|c|c|c|c|}
\hline \multirow[t]{2}{*}{ Procurement Objectives } & \multirow[t]{2}{*}{$\begin{array}{l}\text { Type of } \\
\text { organisation }\end{array}$} & \multirow[t]{2}{*}{$\mathrm{N}$} & \multirow[t]{2}{*}{ Mean } & \multirow[t]{2}{*}{$\begin{array}{l}\text { Std. } \\
\text { Dev. }\end{array}$} & \multirow{2}{*}{$\begin{array}{l}\text { Std. } \\
\text { Error } \\
\text { Mean }\end{array}$} & \multicolumn{3}{|c|}{$\begin{array}{l}\text { Levene's Test for Equality of } \\
\text { Variances }\end{array}$} & \multicolumn{5}{|c|}{ t-test for Equality of Means } \\
\hline & & & & & & $\begin{array}{l}\text { Equality of } \\
\text { Variances }\end{array}$ & $\mathrm{F}$ & Sig. & $\mathrm{t}$ & df & $\begin{array}{l}\text { Sig. (2- } \\
\text { tailed) }\end{array}$ & $\begin{array}{l}\text { Mean } \\
\text { Diff. }\end{array}$ & $\begin{array}{l}\text { Std. } \\
\text { Error } \\
\text { Diff. }\end{array}$ \\
\hline \multirow{2}{*}{ Transparency } & $\begin{array}{l}\text { Local } \\
\text { government }\end{array}$ & 150 & 3.447 & 1.033 & 0.084 & $\begin{array}{l}\text { Equal variances } \\
\text { assumed }\end{array}$ & 2.242 & 0.135 & 0.473 & 286.000 & 0.637 & 0.055 & 0.117 \\
\hline & $\begin{array}{l}\text { State } \\
\text { government }\end{array}$ & 138 & 3.391 & 0.947 & 0.081 & $\begin{array}{l}\text { Equal variances } \\
\text { not assumed }\end{array}$ & & & 0.474 & 285.997 & 0.636 & 0.055 & 0.117 \\
\hline \multirow{2}{*}{ Compliance } & $\begin{array}{l}\text { Local } \\
\text { government }\end{array}$ & 150 & 3.353 & 0.956 & 0.078 & $\begin{array}{l}\text { Equal variances } \\
\text { assumed }\end{array}$ & 2.581 & 0.109 & -0.732 & 285.000 & 0.465 & -0.077 & 0.106 \\
\hline & $\begin{array}{l}\text { State } \\
\text { government }\end{array}$ & 137 & 3.431 & 0.821 & 0.070 & $\begin{array}{l}\text { Equal variances } \\
\text { not assumed }\end{array}$ & & & -0.737 & 283.918 & 0.462 & -0.077 & 0.105 \\
\hline \multirow{2}{*}{ Value-for-money } & $\begin{array}{l}\text { Local } \\
\text { government }\end{array}$ & 150 & 3.467 & 0.988 & 0.081 & $\begin{array}{l}\text { Equal variances } \\
\text { assumed }\end{array}$ & 3.081 & 0.080 & -0.863 & 285.000 & 0.389 & -0.095 & 0.110 \\
\hline & $\begin{array}{l}\text { State } \\
\text { government }\end{array}$ & 137 & 3.562 & 0.873 & 0.075 & $\begin{array}{l}\text { Equal variances } \\
\text { not assumed }\end{array}$ & & & -0.868 & 284.709 & 0.386 & -0.095 & 0.110 \\
\hline \multirow{2}{*}{$\begin{array}{l}\text { Promotion of equality, } \\
\text { diversity and opportunity } \\
\text { (e.g. for SMEs, marginalised } \\
\text { groups in society etc.) }\end{array}$} & $\begin{array}{l}\text { Local } \\
\text { government }\end{array}$ & 150 & 3.167 & 1.026 & 0.084 & $\begin{array}{l}\text { Equal variances } \\
\text { assumed }\end{array}$ & 0.291 & 0.590 & -0.847 & 284.000 & 0.398 & -0.098 & 0.116 \\
\hline & $\begin{array}{l}\text { State } \\
\text { government }\end{array}$ & 136 & 3.265 & 0.921 & 0.079 & $\begin{array}{l}\text { Equal variances } \\
\text { not assumed }\end{array}$ & & & -0.852 & 283.973 & 0.395 & -0.098 & 0.115 \\
\hline \multirow{2}{*}{ Private sector participation } & $\begin{array}{l}\text { Local } \\
\text { government }\end{array}$ & 150 & 2.980 & 1.096 & 0.089 & $\begin{array}{l}\text { Equal variances } \\
\text { assumed }\end{array}$ & 0.840 & 0.360 & -0.876 & 285.000 & 0.382 & -0.108 & 0.123 \\
\hline & $\begin{array}{l}\text { State } \\
\text { government }\end{array}$ & 137 & 3.088 & 0.974 & 0.083 & $\begin{array}{l}\text { Equal variances } \\
\text { not assumed }\end{array}$ & & & -0.881 & 284.790 & 0.379 & -0.108 & 0.122 \\
\hline \multirow{2}{*}{ Innovation } & $\begin{array}{l}\text { Local } \\
\text { government }\end{array}$ & 150 & 3.187 & 1.032 & 0.084 & $\begin{array}{l}\text { Equal variances } \\
\text { assumed }\end{array}$ & 2.417 & 0.121 & -0.242 & 283.000 & 0.809 & -0.028 & 0.116 \\
\hline & $\begin{array}{l}\text { State } \\
\text { government }\end{array}$ & 135 & 3.215 & 0.917 & 0.079 & $\begin{array}{l}\text { Equal variances } \\
\text { not assumed }\end{array}$ & & & -0.244 & 282.958 & 0.808 & -0.028 & 0.115 \\
\hline
\end{tabular}




\begin{tabular}{|c|c|c|c|c|c|c|c|c|c|c|c|c|c|}
\hline Sustainability & $\begin{array}{l}\text { Local } \\
\text { government } \\
\text { State } \\
\text { government }\end{array}$ & $\begin{array}{l}150 \\
137\end{array}$ & $\begin{array}{l}3.307 \\
3.329\end{array}$ & $\begin{array}{l}0.990 \\
0.892\end{array}$ & $\begin{array}{l}0.081 \\
0.076\end{array}$ & $\begin{array}{l}\text { Equal variances } \\
\text { assumed } \\
\text { Equal variances } \\
\text { not assumed }\end{array}$ & 1.411 & 0.236 & $\begin{array}{l}-0.195 \\
-0.196\end{array}$ & $\begin{array}{l}285.000 \\
284.954\end{array}$ & $\begin{array}{l}0.845 \\
0.845\end{array}$ & $\begin{array}{l}-0.022 \\
-0.022\end{array}$ & $\begin{array}{l}0.112 \\
0.111\end{array}$ \\
\hline Accountability & $\begin{array}{l}\text { Local } \\
\text { government } \\
\text { State } \\
\text { government }\end{array}$ & $\begin{array}{l}150 \\
137\end{array}$ & $\begin{array}{l}3.460 \\
3.599\end{array}$ & $\begin{array}{l}0.981 \\
0.951\end{array}$ & $\begin{array}{l}0.080 \\
0.081\end{array}$ & $\begin{array}{l}\text { Equal variances } \\
\text { assumed } \\
\text { Equal variances } \\
\text { not assumed }\end{array}$ & 0.192 & 0.662 & $\begin{array}{l}-1.213 \\
-1.215\end{array}$ & $\begin{array}{l}285.000 \\
283.975\end{array}$ & $\begin{array}{l}0.226 \\
0.225\end{array}$ & $\begin{array}{l}-0.139 \\
-0.139\end{array}$ & $\begin{array}{l}0.114 \\
0.114\end{array}$ \\
\hline $\begin{array}{l}\text { Standardisation of } \\
\text { procurement procedures }\end{array}$ & $\begin{array}{l}\text { Local } \\
\text { government } \\
\text { State } \\
\text { government }\end{array}$ & $\begin{array}{l}150 \\
137\end{array}$ & $\begin{array}{l}3.433 \\
3.489\end{array}$ & $\begin{array}{l}0.986 \\
0.892\end{array}$ & $\begin{array}{l}0.080 \\
0.076\end{array}$ & $\begin{array}{l}\text { Equal variances } \\
\text { assumed } \\
\text { Equal variances } \\
\text { not assumed }\end{array}$ & 2.330 & 0.128 & $\begin{array}{l}-0.500 \\
-0.503\end{array}$ & $\begin{array}{l}285.000 \\
284.977\end{array}$ & $\begin{array}{l}0.617 \\
0.616\end{array}$ & $\begin{array}{l}-0.056 \\
-0.056\end{array}$ & $\begin{array}{l}0.111 \\
0.111\end{array}$ \\
\hline $\begin{array}{l}\text { Competition in procurement } \\
\text { process }\end{array}$ & $\begin{array}{l}\text { Local } \\
\text { government } \\
\text { State } \\
\text { government }\end{array}$ & $\begin{array}{l}150 \\
137\end{array}$ & $\begin{array}{l}3.147 \\
3.321\end{array}$ & $\begin{array}{l}1.083 \\
1.007\end{array}$ & $\begin{array}{l}0.088 \\
0.086\end{array}$ & $\begin{array}{l}\text { Equal variances } \\
\text { assumed } \\
\text { Equal variances } \\
\text { not assumed }\end{array}$ & 0.255 & 0.614 & $\begin{array}{l}-1.410 \\
-1.414\end{array}$ & $\begin{array}{l}285.000 \\
284.908\end{array}$ & $\begin{array}{l}0.160 \\
0.158\end{array}$ & $\begin{array}{l}-0.175 \\
-0.175\end{array}$ & $\begin{array}{l}0.124 \\
0.123\end{array}$ \\
\hline Cost effectiveness & $\begin{array}{l}\text { Local } \\
\text { government } \\
\text { State } \\
\text { government }\end{array}$ & $\begin{array}{l}150 \\
137\end{array}$ & $\begin{array}{l}3.453 \\
3.475\end{array}$ & $\begin{array}{l}1.001 \\
0.867\end{array}$ & $\begin{array}{l}0.082 \\
0.074\end{array}$ & $\begin{array}{l}\text { Equal variances } \\
\text { assumed } \\
\text { Equal variances } \\
\text { not assumed }\end{array}$ & 3.513 & 0.062 & $\begin{array}{l}-0.190 \\
-0.192\end{array}$ & $\begin{array}{l}285.000 \\
284.219\end{array}$ & $\begin{array}{l}0.849 \\
0.848\end{array}$ & $\begin{array}{l}-0.021 \\
-0.021\end{array}$ & $\begin{array}{l}0.111 \\
0.110\end{array}$ \\
\hline Professionalism & $\begin{array}{l}\text { Local } \\
\text { government } \\
\text { State } \\
\text { government }\end{array}$ & $\begin{array}{l}150 \\
137\end{array}$ & $\begin{array}{l}3.687 \\
3.613\end{array}$ & $\begin{array}{l}0.991 \\
0.901\end{array}$ & $\begin{array}{l}0.081 \\
0.077\end{array}$ & $\begin{array}{l}\text { Equal variances } \\
\text { assumed } \\
\text { Equal variances } \\
\text { not assumed }\end{array}$ & 1.021 & 0.313 & $\begin{array}{l}0.655 \\
0.658\end{array}$ & $\begin{array}{l}285.000 \\
284.996\end{array}$ & $\begin{array}{l}0.513 \\
0.511\end{array}$ & $\begin{array}{l}0.074 \\
0.074\end{array}$ & $\begin{array}{l}0.112 \\
0.112\end{array}$ \\
\hline Fairness & $\begin{array}{l}\text { Local } \\
\text { government } \\
\text { State } \\
\text { government }\end{array}$ & $\begin{array}{l}150 \\
136\end{array}$ & $\begin{array}{l}3.360 \\
3.375\end{array}$ & $\begin{array}{l}1.012 \\
0.910\end{array}$ & $\begin{array}{l}0.083 \\
0.078\end{array}$ & $\begin{array}{l}\text { Equal variances } \\
\text { assumed } \\
\text { Equal variances } \\
\text { not assumed }\end{array}$ & 2.150 & 0.144 & $\begin{array}{l}-0.131 \\
-0.132\end{array}$ & $\begin{array}{l}284.000 \\
283.984\end{array}$ & $\begin{array}{l}0.896 \\
0.895\end{array}$ & $\begin{array}{l}-0.015 \\
-0.015\end{array}$ & $\begin{array}{l}0.114 \\
0.114\end{array}$ \\
\hline Environmental protection & $\begin{array}{l}\text { Local } \\
\text { government } \\
\text { State } \\
\text { government }\end{array}$ & $\begin{array}{l}150 \\
137\end{array}$ & $\begin{array}{l}3.500 \\
3.372\end{array}$ & $\begin{array}{l}1.151 \\
1.000\end{array}$ & $\begin{array}{l}0.094 \\
0.085\end{array}$ & $\begin{array}{l}\text { Equal variances } \\
\text { assumed } \\
\text { Equal variances } \\
\text { not assumed }\end{array}$ & 2.743 & 0.099 & $\begin{array}{l}0.999 \\
1.006\end{array}$ & $\begin{array}{l}285.000 \\
284.299\end{array}$ & $\begin{array}{l}0.319 \\
0.315\end{array}$ & $\begin{array}{l}0.128 \\
0.128\end{array}$ & $\begin{array}{l}0.128 \\
0.127\end{array}$ \\
\hline
\end{tabular}


Table 8: Differences in Perceived Level of Attainment of Procurement Objectives - By Location

\begin{tabular}{|c|c|c|c|c|c|c|c|c|c|c|c|c|c|}
\hline \multirow[t]{2}{*}{ Procurement Objectives } & \multirow[t]{2}{*}{ Location } & \multirow[t]{2}{*}{$\mathrm{N}$} & \multirow[t]{2}{*}{ Mean } & \multirow[t]{2}{*}{$\begin{array}{l}\text { Std. } \\
\text { Dev. }\end{array}$} & \multirow{2}{*}{$\begin{array}{l}\text { Std. } \\
\text { Error } \\
\text { Mean }\end{array}$} & \multicolumn{3}{|c|}{$\begin{array}{c}\text { Levene's Test for Equality of } \\
\text { Variances }\end{array}$} & \multicolumn{5}{|c|}{ t-test for Equality of Means } \\
\hline & & & & & & $\begin{array}{l}\text { Equality of } \\
\text { Variances }\end{array}$ & $\mathrm{F}$ & Sig. & $\mathrm{t}$ & df & $\begin{array}{l}\text { Sig. (2- } \\
\text { tailed) }\end{array}$ & $\begin{array}{l}\text { Mean } \\
\text { Diff. }\end{array}$ & $\begin{array}{l}\text { Std. } \\
\text { Error } \\
\text { Diff. }\end{array}$ \\
\hline \multirow{2}{*}{ Transparency } & South & 171 & 3.392 & 1.076 & 0.082 & $\begin{array}{l}\text { Equal variances } \\
\text { assumed }\end{array}$ & 7.227 & 0.008 & -0.585 & 286.000 & 0.559 & -0.070 & 0.119 \\
\hline & North & 117 & 3.462 & 0.856 & 0.079 & $\begin{array}{l}\text { Equal variances not } \\
\text { assumed }\end{array}$ & & & -0.611 & 279.437 & 0.542 & -0.070 & 0.114 \\
\hline \multirow{2}{*}{${ }^{* \star *}$ Compliance } & South & 170 & 3.494 & 0.899 & 0.069 & $\begin{array}{l}\text { Equal variances } \\
\text { assumed }\end{array}$ & 1.427 & 0.233 & 2.394 & & & 0.255 & 0.106 \\
\hline & North & 117 & 3.239 & 0.868 & 0.080 & $\begin{array}{l}\text { Equal variances not } \\
\text { assumed }\end{array}$ & & & 2.409 & 255.112 & 0.017 & 0.255 & 0.106 \\
\hline \multirow{2}{*}{ Value-for-money } & South & 170 & 3.529 & 0.986 & 0.076 & $\begin{array}{l}\text { Equal variances } \\
\text { assumed }\end{array}$ & 2.223 & 0.137 & 0.376 & 285.000 & 0.707 & 0.042 & 0.112 \\
\hline & North & 117 & 3.487 & 0.857 & 0.079 & $\begin{array}{l}\text { Equal variances not } \\
\text { assumed }\end{array}$ & & & 0.386 & 269.880 & 0.700 & 0.042 & 0.110 \\
\hline \multirow{2}{*}{$\begin{array}{l}\text { ***Promotion of equality, } \\
\text { diversity and opportunity (e.g. for } \\
\text { SMEs, marginalised groups in } \\
\text { society etc.) }\end{array}$} & South & 169 & 3.343 & 0.939 & 0.072 & $\begin{array}{l}\text { Equal variances } \\
\text { assumed }\end{array}$ & 1.063 & 0.303 & 2.733 & 284.000 & 0.007 & 0.318 & 0.116 \\
\hline & North & 117 & 3.026 & 1.004 & 0.093 & $\begin{array}{l}\text { Equal variances not } \\
\text { assumed }\end{array}$ & & & 2.700 & 238.598 & 0.007 & 0.318 & 0.118 \\
\hline \multirow{2}{*}{ Private sector participation } & South & 170 & 3.047 & 1.031 & 0.079 & $\begin{array}{l}\text { Equal variances } \\
\text { assumed }\end{array}$ & 0.072 & 0.788 & 0.308 & 285.000 & 0.758 & 0.039 & 0.125 \\
\hline & North & 117 & 3.009 & 1.055 & 0.097 & $\begin{array}{l}\text { Equal variances not } \\
\text { assumed }\end{array}$ & & & 0.307 & 245.803 & 0.759 & 0.039 & 0.126 \\
\hline \multirow{2}{*}{ ***Innovation } & South & 168 & 3.363 & 0.969 & 0.075 & $\begin{array}{l}\text { Equal variances } \\
\text { assumed }\end{array}$ & 3.513 & 0.062 & 3.437 & 283.000 & 0.001 & 0.397 & 0.116 \\
\hline & North & 117 & 2.966 & 0.946 & 0.087 & $\begin{array}{l}\text { Equal variances not } \\
\text { assumed }\end{array}$ & & & 3.452 & 253.441 & 0.001 & 0.397 & 0.115 \\
\hline Sustainability & South & 170 & 3.400 & 0.932 & 0.071 & $\begin{array}{l}\text { Equal variances } \\
\text { assumed }\end{array}$ & 0.982 & 0.323 & 1.803 & 285.000 & 0.072 & 0.203 & 0.113 \\
\hline
\end{tabular}




\begin{tabular}{|c|c|c|c|c|c|c|c|c|c|c|c|c|c|}
\hline & North & 117 & 3.197 & 0.949 & 0.088 & $\begin{array}{l}\text { Equal variances not } \\
\text { assumed }\end{array}$ & & & 1.797 & 246.542 & 0.073 & 0.203 & 0.113 \\
\hline \multirow{2}{*}{ Accountability } & South & 170 & 3.547 & 0.997 & 0.076 & $\begin{array}{l}\text { Equal variances } \\
\text { assumed }\end{array}$ & 1.226 & 0.269 & 0.441 & 285.000 & 0.659 & 0.051 & 0.116 \\
\hline & North & 117 & 3.496 & 0.925 & 0.086 & $\begin{array}{l}\text { Equal variances not } \\
\text { assumed }\end{array}$ & & & 0.447 & 261.150 & 0.655 & 0.051 & 0.115 \\
\hline \multirow{2}{*}{$\begin{array}{l}\text { Standardisation of procurement } \\
\text { procedures }\end{array}$} & & 170 & 3.477 & 0.962 & 0.074 & $\begin{array}{l}\text { Equal variances } \\
\text { assumed }\end{array}$ & 0.388 & 0.534 & 0.358 & 285.000 & 0.720 & 0.041 & 0.113 \\
\hline & North & 117 & 3.436 & 0.913 & 0.084 & $\begin{array}{l}\text { Equal variances not } \\
\text { assumed }\end{array}$ & & & 0.362 & 257.661 & 0.718 & 0.041 & 0.112 \\
\hline \multirow{2}{*}{$\begin{array}{l}\text { Competition in procurement } \\
\text { process }\end{array}$} & South & 170 & 3.277 & 0.985 & 0.076 & $\begin{array}{l}\text { Equal variances } \\
\text { assumed }\end{array}$ & 3.934 & 0.048 & 0.905 & 285.000 & 0.366 & 0.114 & 0.126 \\
\hline & North & 117 & 3.162 & 1.137 & 0.105 & $\begin{array}{l}\text { Equal variances not } \\
\text { assumed }\end{array}$ & & & 0.881 & 225.534 & 0.379 & 0.114 & 0.129 \\
\hline \multirow{2}{*}{ Cost effectiveness } & South & 170 & 3.518 & 0.944 & 0.072 & $\begin{array}{l}\text { Equal variances } \\
\text { assumed }\end{array}$ & 0.058 & 0.809 & 1.182 & 285.000 & 0.238 & 0.133 & 0.113 \\
\hline & North & 117 & 3.385 & 0.927 & 0.086 & $\begin{array}{l}\text { Equal variances not } \\
\text { assumed }\end{array}$ & & & 1.186 & 252.326 & 0.237 & 0.133 & 0.112 \\
\hline \multirow{2}{*}{ Professionalism } & South & 170 & 3.729 & 0.978 & 0.075 & $\begin{array}{l}\text { Equal variances } \\
\text { assumed }\end{array}$ & 0.340 & 0.560 & 1.682 & 285.000 & 0.094 & 0.191 & 0.114 \\
\hline & North & 117 & 3.539 & 0.896 & 0.083 & $\begin{array}{l}\text { Equal variances not } \\
\text { assumed }\end{array}$ & & & 1.709 & 262.896 & 0.089 & 0.191 & 0.112 \\
\hline \multirow{2}{*}{ Fairness } & South & 169 & 3.444 & 0.963 & 0.074 & $\begin{array}{l}\text { Equal variances } \\
\text { assumed }\end{array}$ & 0.297 & 0.586 & 1.622 & 284.000 & 0.106 & 0.187 & 0.116 \\
\hline & North & 117 & 3.256 & 0.957 & 0.089 & $\begin{array}{l}\text { Equal variances not } \\
\text { assumed }\end{array}$ & & & 1.624 & 250.512 & 0.106 & 0.187 & 0.115 \\
\hline \multirow{2}{*}{ 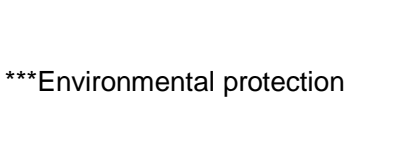 } & South & 170 & 3.565 & 1.093 & 0.084 & $\begin{array}{l}\text { Equal variances } \\
\text { assumed }\end{array}$ & 0.687 & 0.408 & 2.392 & 285.000 & 0.017 & 0.308 & 0.129 \\
\hline & North & 117 & 3.256 & 1.043 & 0.096 & $\begin{array}{l}\text { Equal variances not } \\
\text { assumed }\end{array}$ & & & 2.413 & 256.775 & 0.017 & 0.308 & 0.128 \\
\hline
\end{tabular}

Note: ${ }^{* * *}$ Indicates significant difference in Mean scores (i.e. p-value $\leq 0.05$ ) 